\title{
How withdrawing arable land affected the productive capacity of Haplic Kastanozems after 19 years of fallowing in dry steppes of the Ural piedmont
}

\author{
Saule Rakhimgaliyeva ${ }^{1}$, Sonja Tošic ${ }^{2}$, Frank Eulenstein $^{3}$, Uwe Schindler $^{4}$, Elmira Saljnikov $^{2 *}$
}

\author{
${ }^{1}$ West Kazakhstan Agrarian Technical University, Zhangir Khan 51, Uralsk, Kazakhstan \\ ${ }^{2}$ Soil Science Institute, TeodoraDrajzera 7,11000 Belgrade, Serbia \\ ${ }^{3}$ Leibniz-Centre for Agricultural Landscape Research (ZALF), 15374 Müncheberg, Eberswalder Str. 84, Germany, \\ ${ }^{4}$ Mitscherlich Academy for Soil Fertility (MITAK), GmbH, 14641 Paulinenaue, Prof.-Mitscherlich-Allee 1, \\ Germany,
}

*Corresponding author: Elmira Saljnikov, soils.saljnikov@gmail.com

\begin{abstract}
The fertile arable lands in the dry steppe zone of the Ural piedmont, which were intensively used for cereal production for 30 years of the last century, have been withdrawn from cultivation and abandoned for the last 20 years. The Republic of Kazakhstan's new strategy to restore the productivity of natural pasture presents a challenge to scientists when it comes to restoring the natural soil properties to the natural pastoral conditions of the dark chestnut soils studied (Haplic Kastanozems). This chapter presents the results of a project devoted to investigating the changes in the soil's physical and chemical morphology due to the past cultivation history of Haplic Kastanozem soils that have been in a fallow state for the last 19 years. Some changes in the soils' morphological characteristics were caused by the changes in the soils' physical properties due to their past long-term cultivation. The changes observed in the soils' agrochemical characteristics were due to the changes in the soils' physical properties and to the past fertilization history. A minor increase in soil salinity was observed due to the greater accumulation of soluble salts in the arable layer of fallow soil compared to its virgin Haplic Kastanozem analogue. The changes and transitions in the vegetation composition need to be investigated further, and techniques should be developed for the accelerated restoration of fallow soils in dry-steppes of Western Kazakhstan.
\end{abstract}

Keywords: Haplic Kastanozem, Fallow soil, Virgin soil, Flora, Morphology, Humus, Particle size distribution, Soluble salts

\section{Introduction}

The United Nations reported that in the Republic of Kazakhstan the area of degraded unproductive lands that need improvement comprises 179.9 million hectares out of 222.5 million ha of agricultural lands (Espolov et al. 2006). The abandoned arable lands that have been in a fallow state for the past 20 years are included in the urgent list of lands requiring rehabilitation. The dry lands of Kazakhstan were traditionally and historically used as rangelands with a rich biodiversity of steppe herbs. In the middle of the $20^{\text {th }}$ century, most fertile virgin steppe lands in Kazakhstan were brought to cultivation to increase grain production in the Soviet Union. In the 1990s, large areas of arable lands were abandoned due to a decline in cereal production and the wide-scale withdrawal of land from agricultural usage. Over the past 20 years, millions 
of hectares of abandoned arable lands (fallow lands) in Western Kazakhstan have been neither used nor studied.

The Dark Chestnut soils of the dry steppes of the West Kazakhstan region are zonal soils whose morphology and genesis have been thoroughly studied in the past (Rakhimgaliyeva and Khudyakova 2010; Rakhimgaliyeva and Khudyakova 2011; Khudyakova 2015). Dry steppe soil formation is characterized by the soil CEC being saturated with $\mathrm{Ca}_{2}{ }^{+}$and $\mathrm{Mg}_{2}{ }^{+}$and the absence of leaching of sesquioxides and clay due to a non-percolating water regime. Chestnut soils of the dry steppes are usually alkaline and saline. Earlier studies showed that most of the arable Dark Chestnut soils are morphologically very similar to their adjoining virgin analogues (Rakhimgaliyeva et al. 2013). However, Kovda (1947) reported that when cultivated steppe solonetzic chestnut soils are withdrawn from agricultural use, they cannot completely recover the original vegetation cover characteristics of their virgin analogues.

Abandoned agricultural land is often referred to as degraded, and the degree of abandonees of fallow land is considered as an indicator of degradation (Edelgeriev 2019). When the soil is withdrawn from agricultural use, agrocenosis is replaced by postagrogenic phytocenosis, characterized by a different composition and vegetation structure on temporal and spatial scales (Koniak and Noy-Meir 2009; Suleymanov et al 2020). Karavaev and Denisenko (2008) divided the development of withdrawn Chernozem soils into four phases: $1^{\text {st }}$ year fallow: pioneer phase; 3-4 years: long rhizome (wheatgrass) phase; 15 years: loose-bush (meadow)-forb-grass phase; 30-50 years: loose-bush-grass-forb-feather grass phase. Lebedeva (2008) studied soil formation processes in fallow dark Chernozem soils abandoned for 50 years under recovered steppe vegetation and found that the soil $\mathrm{pH}$ was neutral in the upper horizon of the humus layer and weakly alkaline lower in the profile, while the composition and the content of salts were similar to the control (virgin) site, which was located two meters away and was leached from soluble salts Suleymanov et al (2020).

Changes in the vegetation composition and structure result in a change in the regularities governing the formation and functioning of soils, which in turn leads them to evolve and causes a significant change in their ecological functions (Edelgeriev 2019). Changes in landuse may results in changes in morphological pattern of soil profile, composition of soil organic matter and soil physical properties as well as nitrogen and phosphorus re-distribution (Shang et al. 2019) and biological properties of soil such as rate of decomposition of OC, enzymatic activity and microorganism community (Telesnina and Zhukov 2019). Kazeev et al (2020) reported that the organic carbon content in the soil of the young fallow increased already in the first year. In addition, changes in the content of organic matter in soils under long-term agricultural use have been broadly studied by many researchers, however fewer studies have an insight into the whole soil profile (Follett et al. 2009), and researchers have only rarely compared the soil properties of arable, fallow and virgin soils deeper than 30 to $45 \mathrm{~cm}$. Short-term human activities may result in a long-term soil 
change (Veenstra and Burras 2015). In dry steppes of western Kazakhstan, many of the above issues were not studied, particularly in a whole depth of soil profile. Because the recent agricultural development strategy in Kazakhstan is to restore natural pasturelands and develop animal husbandry, understanding the regularities and transitions of former arable land into natural pasture is important and is of unquestionable fundamental and applied significance. To achieve this goal, a detailed study of dry steppe soils with a history of long-term cultivation and long-term withdrawal in Kazakhstan is an urgent task. The main goal of this study was to establish the fertility of fallow land that was cultivated for about 30 years for grain production, then withdrawn from agricultural use in the 1990s and abandoned for 19 years in a fallow state. The main hypothesis was that the structure and soil organic matter content of the upper layer of the soil profile of fallow dark chestnut Haplic Kastanozem (WRB 2015) soil differs from its virgin analogue due to past long-lasting agronomic practices. The tasks included a comparison of the morphological, physical and agrochemical parameters of the fallow and adjoining virgin dark chestnut soil properties.

\section{Materials and methods Site description}

The territory studied was located within the Ural Plateau on the watershed section, between the rivers Ilek, Chile and Berezovka, which share a northeast slope. The relief is divided into four geomorphological regions: 1) undulated hilly plain; 2) weak undulated plain; 3) rugged undulated plain; 4) floodplain of the river Ilek. The main soil-forming rocks (Quaternary and modern sediments) with a heavy mechanical composition resulted in the formation of clay and heavy loamy soils. In most cases, the rocks are saline to varying extents. The climate of the territory studied is very arid and warm. The average annual precipitation is around 200-220 mm. Thus, the natural vegetation was formed in the conditions of an insufficient, unstable moisture supply.

Soil profiles were taken on October 2013 on Haplic Kastanozems respectively in a virgin state and fallowed for 19 years in the Ashesai district of the Ural region of West Kazakhstan. The geobotanical survey of virgin and fallow plots was carried out using the transect method during the vegetation periods. The collection of materials, observations and analysis of flora were carried out according to the standard methods described by Shennikov and Maevsky (1964). The similarity between the communities' floristic diversity was assessed using the Jaccard coefficient,

$$
K=\frac{c \cdot 100}{a+b-c}
$$

where $c$ is the number of common species in compared communities, while $a$ and 8 are the numbers of species in each of the communities. 


\section{Laboratory analyses}

The particle size distribution was determined by the densimeter method based on sedimentation velocity in a liquid (Mineev2001). The soil pH was determined potentiometrically on a glass electrode $\mathrm{pH}$ meter. The soil organic matter was determined using the Tyurin wet-combustion method based on oxidation of a small portion of the soil with potassium dichromate, followed by titration of the excess potassium dichromate with Mohr's salt (Mineev 2001). The hydrolyzable nitrogen was determined by hydrolysis of soil organic compounds with $1 \mathrm{~N}$ of $\mathrm{NaOH}$ solution. The ammonia released during this process was determined using the microdiffusion method (Mineev 2001).

The total content of phosphorus was determined after combusting soil samples in a mixture of concentrated sulphuric acid and 50\% hydrochloric acid (10:1), followed by the colorimetric determination of phosphorus (Mineev 2001). Mobile phosphorus and potassium content was determined using the Machigin method (Mineev 2001), which is the standard method for calcareous chestnut soils and is based on an extraction of mobile $\mathrm{P}$ and $\mathrm{K}$ from soil using $1 \%$ solution of ammonium carbonate with pH 9.0 at $25^{\circ} \mathrm{C}$, with a soil-to-solution ratio of 1:20.

Soil absorption capacity was determined by the method proposed by Gedroitz for calcareous soils. It is based on saturating the soil with sodium, which is subsequently displaced from the soil by calcium of calcium bicarbonate after adding dry chalk powder, in the presence of a sufficient amount of water, to a stream of carbon dioxide (Mineev 2001).

The quantity and quality of soluble salts were determined in a water extraction of soil samples, followed by the determination of anions and cations. Carbonates were determined by back-titration with sulfuric acid until $\mathrm{pH} 8.3$, and bicarbonates until $\mathrm{pH}$ 4.4. Concentration of chlorides was determined by titration with silver nitrate; sulfate ions were determined based on its ability to form stable precipitate with $\mathrm{Ba}^{++}$and weighing ignition residue. The $\mathrm{Na}^{+}$concentrations in water extraction were determined with a flame photometer at a wavelength of $589 \mathrm{~nm}$; and concentrations of $\mathrm{Ca}^{++}, \mathrm{Mg}^{++}$were determined with an atomic-absorption analyzer (Mineev 2001).

\section{Results and discussions Soil morphological characteristics}

The morphological description of the profiles studied is presented in Table 1. Differences were observed in the morphological characteristics of virgin and fallow soils. The humified A1 horizon of virgin Haplic Kastanozem soil was $18 \mathrm{~cm}$ thick with the greatest amount of humus in the surface horizon A1, while the adjoining fallow soil had a $23 \mathrm{~cm}$ thick A1 horizon. However, the overall humus layer (A1+B1) was shortened in fallow soil by $3 \mathrm{~cm}$. 
After the termination of cultivation, the border of effervescence was shifted upward. The abundance of roots in the B1 horizon of fallow soil versus a few scattered roots in the same horizon of virgin soil indicates the differences in vegetation composition. The clear transition in the density from the B1 to B2 horizon in fallow soil was a result of annual plowing until 1993.

Table 1. Morphological description of the studied virgin and abandoned fallow Dark Chestnut soil

\begin{tabular}{|c|c|c|c|}
\hline \multicolumn{2}{|r|}{ Haplic Kastanozem, virgin } & \multicolumn{2}{|c|}{ Haplic Kastanozem, 19 years in fallow } \\
\hline Horizon & Description & Horizon & Description \\
\hline $\begin{array}{l}\text { A1 } \\
(0.5-18)\end{array}$ & $\begin{array}{l}\text { Dark gray, heavy clayey, abundant roots, } \\
\text { dry, loosely crumbly structure, dense, no } \\
\text { effervescence, clear transition }\end{array}$ & $\begin{array}{l}\text { A1 } \\
(0-23)\end{array}$ & $\begin{array}{l}\text { Dark gray, heavy clayey, abundant roots, } \\
\text { dry, loosely crumbly structure, dense, weak } \\
\text { effervescence from surface, gradual } \\
\text { transition by color, and clear by density }\end{array}$ \\
\hline $\begin{array}{l}\text { B1 } \\
(18-40)\end{array}$ & $\begin{array}{l}\text { Gray, heavy clayey, few roots, dry, } \\
\text { prismatic-nutty structure, dense, weak } \\
\text { effervescence from } 27 \mathrm{~cm} \text {, clear transition } \\
\text { by color }\end{array}$ & $\begin{array}{l}\text { B1 } \\
(23-37)\end{array}$ & $\begin{array}{l}\text { Gray, heavy clayey, abundant roots, dry, } \\
\text { prismatic-nutty structure, dense, vigorous } \\
\text { effervescence, clear transition by color and } \\
\text { by density }\end{array}$ \\
\hline $\begin{array}{l}\text { B2 } \\
(40-61)\end{array}$ & $\begin{array}{l}\text { Pale, heavy clayey, few roots, dry, } \\
\text { prismatic-nutty structure, very dense, } \\
\text { vigorous effervescence, clear transition } \\
\text { by color }\end{array}$ & $\begin{array}{l}\text { B2 } \\
(37-57)\end{array}$ & $\begin{array}{l}\text { Brown, heavy clayey, heavy clayey, few } \\
\text { roots, dry, prismatic-nutty structure, very } \\
\text { dense, vigorous effervescence, clear } \\
\text { transition by color }\end{array}$ \\
\hline $\begin{array}{l}\text { Вк } \\
(61- \\
100) \\
\end{array}$ & $\begin{array}{l}\text { Pale, heavy clayey, 'white eye' } \\
\text { carbonates, vigorous effervescence, } \\
\text { coarse prismatic structure, dense }\end{array}$ & $\begin{array}{l}\text { Вк } \\
(57-100)\end{array}$ & $\begin{array}{l}\text { Pale, heavy clayey, few roots, dry, 'white } \\
\text { eye' carbonates, nutty-coarse-prismatic } \\
\text { structure, dense, vigorous effervescence }\end{array}$ \\
\hline
\end{tabular}

The observed increased depth of the A1 horizon in fallow soil compared to its virgin analogue was linked to the 30 years of tillage, when soil was annually plowed by traditional deep plow machines, during which the upper humified soil layers penetrated and mixed with lower horizons (Veenstra and Burras 2015).

\section{Soil particle size distribution}

In soil particle size composition, clay and the fine silt fraction play an important role, ensuring that the colloidal fraction of the soil is active and thus causing the accumulation of cations and organic matter. During the transformations of Haplic Kastanozem soils into arable lands, followed by their withdrawal from agricultural use for 19 years, their particle size composition also changed in terms of the redistribution of soil particle sizes (Table 2). The virgin and fallow soils studied each had a heavy, clayey texture, with the fractions of fine sand and coarse silt dominating in the virgin soil, while the fractions of fine sand and clay dominated in the fallow soil.

A clear re-distribution of the soil particles was observed in the A1 horizon of fallow soil. In virgin soil, the fractions which were $1-0.01 \mathrm{~mm}$ in size were greater than in the fallow analogue, while the $0.01-$ $0.005 \mathrm{~mm}$ fractions were almost the same. However, the content of $0.005-0.001 \mathrm{~mm}$ particles was lower in virgin than in fallow soil. The content of $<0.001 \mathrm{~mm}$ fractions in the fallow soil increased by $4.15 \%$ 
compared to its virgin analogue, but in underlying horizons its content sharply decreased in fallow soil. A similar trend was observed for the fraction of physical clay $(<0.01 \mathrm{~mm})$. The amount of physical clay in the A1 horizon of fallow soil was $7.11 \%$ greater than in virgin soil.

Table 2. Granulometric composition of Haplic Kastanozem

\begin{tabular}{|c|c|c|c|c|c|c|c|c|}
\hline \multirow{2}{*}{ Horizons, $\mathrm{cm}$} & \multicolumn{7}{|c|}{ Size of soil particles $(\mathrm{mm})$ and their content $(\%)$} & \multirow{2}{*}{ Soil texture } \\
\hline & $\begin{array}{c}1.00- \\
0.25\end{array}$ & $\begin{array}{c}0.25- \\
0.05\end{array}$ & $\begin{array}{c}0.05- \\
0.01\end{array}$ & $\begin{array}{l}0.01- \\
0.005\end{array}$ & $\begin{array}{c}0.005- \\
0.001\end{array}$ & $<0.001$ & $\begin{array}{c}<0.01 \\
\text { clay }\end{array}$ & \\
\hline \multicolumn{9}{|c|}{ Haplic Kastanozem, virgin } \\
\hline $\mathrm{A} 1(0.5-18)$ & 6.20 & 20.69 & 22.45 & 16.40 & 16.61 & 17.65 & 50.71 & Heavy, \\
\hline B1 $(18-40)$ & 1.02 & 26.07 & 18.50 & 14.79 & 20.06 & 19.56 & 54.41 & clayey \\
\hline $\mathrm{B} 2(40-61)$ & 0.89 & 15.56 & 19.99 & 16.31 & 24.56 & 22.69 & 63.56 & coarse-dusty \\
\hline $\mathrm{BC}(61-100)$ & 0.84 & 16.07 & 22.07 & 19.42 & 19.37 & 22.23 & 61.02 & \\
\hline \multicolumn{9}{|c|}{ Haplic Kastanozem, 19 years in fallow } \\
\hline $\mathrm{A} 1(0-23)$ & 4.29 & 19.22 & 18.67 & 16.39 & 19.63 & 21.80 & 57.82 & Heavy, \\
\hline $\mathrm{B} 1(23-37)$ & 2.11 & 25.57 & 20.93 & 17.35 & 16.49 & 17.55 & 51.39 & clayey \\
\hline B2(37-57) & 0.09 & 24.26 & 16.90 & 19.81 & 19.34 & 19.60 & 58.75 & fine dusty- \\
\hline $\mathrm{BC}(57-100)$ & 1.44 & 22.09 & 19.59 & 20.60 & 19.17 & 17.11 & 56.88 & silty \\
\hline
\end{tabular}

The past cultivation of dark chestnut soils has clearly led to an increase in the degree of differentiation of the silt fraction in the profile of arable land. Suleymanov et al (2020) who found a plough pan formed at the depth of 20-35 cm in the fallow postagrogenic ecosystems 18-20 years after the land was withdrawn from cultivation in South Ural reported similar results.) The effect of past intensive cultivation using heavy machinery has long lasting aftereffect on soil compactness, which may take up to 90-year period (Kechaikina et al 2011). Some evidence was observed suggesting that a slight leaching of silt took a place in the uppermost humus horizons of the virgin soils. However, long-term cultivation resulted in a significant eluviation of the silt fraction. Meanwhile, further long-term fallowing of Haplic Kastanozems led to a significant decrease in the thickness of the eluvial silt horizons. Our results in line with findings of Xie et al (2016) who found that even after shorter periods of cultivation $(5,10$ and 15 years), the fraction $<10 \mu \mathrm{m}$ in soil particle size increased by $8.5,19.3$ and 20.3 percentage points, respectively, compared with a natural meadow site.

\section{Soil organic matter and bulk density}

Past intensive exploitation of Haplic Kastanozem resulted in a decrease in the humus content. In Mollic soils, most organic matter losses usually happen after they are brought to cultivation. Table 3 presents the content and reserves of soil humus in the studied virgin and fallow Haplic Kastanozems. We expected that 
19 years of fallowing might contribute to an additional input of moisture into the soil, causing the development of a more powerful root system followed by higher aboveground biomass, which after returning to the soil would contribute to the overall soil organic matter.

Table 3. Humus contents and reserves in Haplic Kastanozem virgin and fallow soils

\begin{tabular}{|c|c|c|c|c|c|c|c|c|c|c|}
\hline \multirow[t]{2}{*}{$\begin{array}{l}\text { Horizon, } \\
\text { cm }\end{array}$} & \multirow[t]{2}{*}{$\mathrm{pH}$} & \multirow{2}{*}{$\begin{array}{c}\begin{array}{c}\text { Bulk } \\
\text { density }\end{array} \\
\mathrm{g} \mathrm{m}^{-3}\end{array}$} & \multirow{2}{*}{$\begin{array}{c}\text { Content } \\
\text { of soil } \\
\text { humus }\end{array}$} & \multirow{2}{*}{$\begin{array}{c}\text { Reserves } \\
\text { of soil } \\
\text { humus }\end{array}$} & \multirow{2}{*}{$\begin{array}{c}\text { Reserves } \\
\text { at } \\
0-20 \mathrm{~cm}\end{array}$} & \multirow[t]{2}{*}{$\begin{array}{c}\text { Reserves } \\
\text { at } \\
0-100 \\
\mathrm{~cm} \\
\mathrm{t} \mathrm{ha}^{-1}\end{array}$} & \multicolumn{2}{|c|}{$\begin{array}{c}\text { Decrease }(-), \\
\text { increase }(+) \\
0-20 \mathrm{~cm}\end{array}$} & \multicolumn{2}{|c|}{$\begin{array}{c}\text { Decrease }(-) \text {, } \\
\text { increase }(+) \\
0-100 \mathrm{~cm}\end{array}$} \\
\hline & & & & & & & $\mathrm{t} \mathrm{ha}^{-1}$ & $\%$ & $\mathrm{t} \mathrm{ha}^{-1}$ & $\%$ \\
\hline \multicolumn{11}{|c|}{ Haplic Kastanozem, virgin } \\
\hline $\mathrm{A} 1(0.5-18)$ & $7.2 \mathrm{a} \dagger$ & $1.35 \mathrm{a}$ & $2.01 \mathrm{a}$ & $47.63 \mathrm{a}$ & 54.43 & 84.53 & & & & \\
\hline $\mathrm{B} 1(18-40)$ & $7.2 \mathrm{a}$ & $1.43 \mathrm{ab}$ & $0.75 b$ & $23.68 b$ & & & & & & \\
\hline $\mathrm{B} 2(40-61)$ & $7.3 \mathrm{a}$ & $1.57 \mathrm{~b}$ & $0.40 \mathrm{c}$ & $13.22 \mathrm{c}$ & & & & & & \\
\hline $\begin{array}{l}\mathrm{BC}(61- \\
100)\end{array}$ & $7.5 \mathrm{a}$ & & traces & 0.00 & & & & & & \\
\hline \multicolumn{11}{|c|}{ Haplic Kastanozem, 19 years in fallow } \\
\hline $\mathrm{A} 1(0-23)$ & $7.2 \mathrm{a}$ & $1.47 \mathrm{ab}$ & $1.86 \mathrm{a}$ & $62.89 \mathrm{~d}$ & 54.69 & 86.78 & +0.26 & +0.47 & +2.25 & +2.59 \\
\hline $\mathrm{B} 1(23-37)$ & $7.2 \mathrm{a}$ & $1.56 \mathrm{~b}$ & $0.66 \mathrm{~b}$ & $14.43 \mathrm{c}$ & & & & & & \\
\hline $\mathrm{B} 2(37-57)$ & $7.3 \mathrm{a}$ & $1.57 \mathrm{~b}$ & $0.30 \mathrm{c}$ & $9.46 \mathrm{e}$ & & & & & & \\
\hline $\begin{array}{l}\mathrm{BC}(57- \\
100)\end{array}$ & $7.5 \mathrm{a}$ & & traces & 0.00 & & & & & & \\
\hline
\end{tabular}

$\dagger$ the different letters signify statistically significant differences within a column

The humus content in the A1 and B1 horizons of fallow soil was reduced by $0.30 \%$ compared to the virgin analogue.

Due to their long-term cultivation history, the soils of fallow land had higher bulk density values in their A1 and B1 horizons (Table 3). Even the termination of cultivation and 19 years of fallowing did not return the soil bulk density to its original state. The increased compactness of the previously cultivated fallow soil comes from the influence of heavy machinery for a period of 30 years (Keller et al 2019). Many studies reported that soil bulk densities from 1.3 to $1.7 \mathrm{mg} \mathrm{m}^{-3}$ may limit root growth and decrease plant yield (Kodiwo et al. 2014). Gumarova et al (2017) reported that the bulk density of the aging fallow soil begins to decrease gradually and approach the indicators of virgin soil, apparently due to the accumulation of plant residues, while on active arable land the bulk density increases.

Although the humus reserves in the A1 horizon of fallow soil were $15.26 \mathrm{t} \mathrm{ha}^{-1}$ higher than in the adjoining virgin soil, due to differences in soil bulk density, in the $0-20 \mathrm{~cm}$ and $0-100 \mathrm{~cm}$ soil layers the humus reserves were not significantly different. The observed increases in the humus content in fallow soil were 0.47 and $2.59 \%$, for soil depths of 20 and $100 \mathrm{~cm}$, respectively. This change was predominantly due to the accumulation of annual plant residues mostly in the upper $23 \mathrm{~cm}$ of soil, since, as discussed earlier, the root penetration might be partially limited by higher soil compactness. This assumption is confirmed by the significantly lower amount of humus in B1 and B2 horizons in fallow soil versus its virgin analogue. 
In the past, the fallow land studied had been cultivated for spring cereals for about 30 years, with corresponding levels of mechanical disturbance. This intensified oxidation processes in the soil and accelerated the mineralization of the SOM (Saljnikov et al 2017). Also, because of a sharp decrease in the belowground biomass and harvested aboveground biomass, the overall input of organic substrate into the soil was substantially decreased. This is especially true under the circumstances of an absence or very low input of mineral fertilizers during the cultivation of spring cereals.

Over 19 years of fallowing the studied soils, the vegetation diversity gradually underwent transformations and transitions through self-growth (Zhang et al. 2018). Since the studied soils were located far from farms and settlements, cattle grazing and hey harvesting were not carried out here. Then, because all grass biomass has been returned into the soil, the humus reserves showed an increasing trend both in 20 and $100 \mathrm{~cm}$ soil layers for 19 years. It is known that the vertical distribution of humus along soil profile is primarily determined by bioclimatic conditions (Hobley et al. 2013). In the conditions of $300 \mathrm{~mm}$ of rainfall, soil cultivation exerts a considerable effect on the accumulation of soil moisture. In a steppe ecosystem 70 to $90 \%$ of plant biomass is concentrated belowground (Titlyanova et al 1984) and therefore tillage causes an extensive reorganization of annual cycles of plant input and soil organic matter dynamics.

\section{Hydrolysable nitrogen}

Nitrogen is the most important nutrient for plant growth and one of the indicators of soil fertility. Hydrolysable nitrogen $\left(\mathrm{N}_{\mathrm{hyd}}\right)$ is the most available $\mathrm{N}$ source for plants. The degree of $\mathrm{N}$ mineralization depends on many factors; primarily the soil moisture and temperature, type of land management, cropping culture etc. (Kadono et al. 2008; Saljnikov et al. 2013; Risch et al 2019; Li et al 2020). Table 4 presents the amount and reserves of hydrolysable $\mathrm{N}$ in the soils studied. The maximum amount of hydrolysable $\mathrm{N}$ was recorded in the upper horizon for both soils. The reserves of easily hydrolyzed nitrogen at $0-20 \mathrm{~cm}$ in virgin dark chestnut soil were increased by $2.11 \%$, while at $0-100 \mathrm{~cm}$ they decreased by $6.8 \%$. The distribution of hydrolysable $\mathrm{N}$ in the soil profiles followed the same trend as the soil humus. The increase in $\mathrm{N}_{\text {hyd }}$ reserves in the A horizon of fallow soil was $2.11 \%$ greater than in virgin soil. However, in the $0-10 \mathrm{~cm}$ soil layer there was an observed decrease by $6.8 \%$ in the reserves of $\mathrm{N}_{\text {hyd }}$ in fallow compared with virgin soil (Table 4).

Virgin grassland soils are rich in labile organic matter due to the yearly input of above- and belowground biomass into the soil (Funakawa et al. 2007; Kadono et al. 2008; Hoffland et al 2020). However, during the first years of tillage, the amount of labile forms of SOM sharply decreases in this soil. In our research, the higher amount of $\mathrm{N}_{\text {hyd }}$ in the upper horizon of fallow soils indicates that labile OM was accumulated during the 19 years of non-cultivation. However, the deeper soil layers still did not restore the initial amount of labile $\mathrm{N}$ in the soil. One of the reasons for this vertical distribution of $\mathrm{N}_{\text {hyd }}$ in fallow land, 
apart from the time factor, should probably be considered to be the increased soil bulk density value in the lower soil layers, which limited root penetration and thus the deposition of the root biomass at deeper layers. The same reason probably explains the higher $\mathrm{N}_{\text {hyd }}$ in the surface horizon, when above- and belowground biomass depositions were concentrated in the upper soil layer.

Table 4. Content and reserves of hydrolysable nitrogen in Haplic Kastanozem

\begin{tabular}{|c|c|c|c|c|c|c|c|c|}
\hline \multirow[t]{2}{*}{ Horizon, $\mathrm{cm}$} & \multirow{2}{*}{$\begin{array}{c}\text { Hydrolysable } \\
\mathrm{N}, \\
\mathrm{mg} 100 \mathrm{~g}^{-1}\end{array}$} & \multicolumn{3}{|c|}{ Reserves of hydrolysable $\mathrm{N}, \mathrm{kg} \mathrm{ha}^{-1}$} & \multicolumn{4}{|c|}{ decrease $(-)$ or increase $(+)$} \\
\hline & & $\begin{array}{c}\text { A1 } \\
\text { horizon }\end{array}$ & $0-20 \mathrm{~cm}$ & $0-100 \mathrm{~cm}$ & $\begin{array}{l}\mathrm{kg} \mathrm{ha}^{-1} \mathrm{at} \\
0-20 \mathrm{~cm}\end{array}$ & $\begin{array}{l}\% \text { at } 0- \\
20 \mathrm{~cm}\end{array}$ & $\begin{array}{c}\mathrm{kg} \mathrm{ha}^{-1} \mathrm{at} \\
0-100 \\
\mathrm{~cm}\end{array}$ & $\begin{array}{l}\% \text { at } 0- \\
100 \mathrm{~cm}\end{array}$ \\
\hline \multicolumn{9}{|c|}{ Haplic Kastanozem, virgin } \\
\hline $\mathrm{A} 1(0.5-18)$ & $20.93 a$ & $495.69 \mathrm{a}$ & 566.50 & 1593.5 & & & & \\
\hline $\mathrm{B} 1(18-40)$ & $18.01 \mathrm{a}$ & $566.59 b$ & & & & & & \\
\hline B2(40-61) & $15.91 \mathrm{ab}$ & $531.23 b$ & & & & & & \\
\hline $\mathrm{BC}(61-100)$ & Traces & 0.0 & & & & & & \\
\hline \multicolumn{9}{|c|}{ Haplic Kastanozem,19 years in fallow } \\
\hline $\mathrm{A} 1(0-23)$ & $19.67 \mathrm{a}$ & $666.55 c$ & 578.74 & 1485.0 & +12.24 & 2.11 & -108.5 & 6.8 \\
\hline $\mathrm{B} 1(23-37)$ & $15.68 \mathrm{ab}$ & $342.45 d$ & & & & & & \\
\hline $\mathrm{B} 2(37-57)$ & $15.03 \mathrm{ab}$ & $475.95 \mathrm{a}$ & & & & & & \\
\hline $\mathrm{BC}(57-100)$ & traces & 0.0 & & & & & & \\
\hline
\end{tabular}

$\uparrow$ the different letters signify statistically significant differences within a column

\section{Soil phosphorus and potassium}

In dry steppe conditions, the uptake of phosphorus compounds depends on the availability of water and air to the soil, the content of other elements, plant characteristics and other factors. The profile distribution of $\mathrm{P}$ accumulation is related to the rock source of the soil parent materials, the degree of the profile development, past fertilization, and removals of soil materials by erosion (Nunes et al 2020; Alewell et al 2020). Table 5 presents the results of soil $\mathrm{P}$ in the studied soils. The studied soils exhibited a low phosphorus content in both profiles, but both the total content of $\mathrm{P}$ and its mobile forms were significantly higher in fallow soil than in its virgin analogue. The same trend was observed for the reserves of $\mathrm{P}$ in the studied soils. The reserves of mobile $\mathrm{P}$ at $0-20 \mathrm{~cm}$ in fallow soil were $27.4 \%$ higher than in virgin soil, while its reserves at $0-50 \mathrm{~cm}$ in fallow soil were $40 \%$ higher than in its virgin analogue. In general, the phosphorus solubility continues to decrease with the passing of time, the rate depending on the soil type (Helfenstein et al 2020).

The rate of replenishment, which determines the availability of $\mathrm{P}$, is related to the soil $\mathrm{pH}$, the $\mathrm{P}$ levels in soil, its fixation by the soil, and the placement of added P. At very high pHs, phosphorus can react with excess calcium to form unavailable compounds via surface adsorption and precipitation in the soil, depressing its availability after fertilizer application (Ray 2006). In our study, past P fertilization resulted in a greater accumulation of $\mathrm{P}$ in fallow soils, where the excess and lay shallow 'free carbonates' of the drycalcareous soil easily interacted with added mineral phosphate and soil $\mathrm{Ca}$ ions to produce dicalcium 
phosphate that as a product of orthophosphate reaction with $\mathrm{CaCO}_{3}$. Further it can be stronger bound and transformed into less soluble forms (e.g., tricalcium or octacalcium phosphate), as well as $\mathrm{P}$ adsorbed on calcite surfaces (Toner and Catling 2020). The later might result in a decrease in the solubility and availability of soil P (Weeks Jr and Hettiarachchi 2019). Schlesinger (1998) studied a desert soil chronosequence in New Mexico and found that Ca-bound $\mathrm{P}$ remained the single largest $\mathrm{P}$ fraction throughout the sequence, while pedogenic $\mathrm{CaCO}_{3}$ was the primary geochemical agent capable of the fixing and retaining $\mathrm{P}$ within the soil profile (Lajtha and Bloomer 1988).

Table 5. Content and reserves of $P$ in virgin and fallow Dark Chestnut soil

\begin{tabular}{|c|c|c|c|c|c|c|}
\hline Horizon & $\begin{array}{l}\text { Depth, } \\
\text { cm }\end{array}$ & $\begin{array}{l}\text { Content of } \\
\text { total } \mathrm{P}, \%\end{array}$ & $\begin{array}{c}\text { Reserves } \\
\text { of total } \\
\mathrm{P}, \mathrm{t} \mathrm{ha}^{-1}\end{array}$ & $\begin{array}{c}\text { Content of mobile } \mathrm{P}, \\
\mathrm{mg} \mathrm{kg}^{-1}\end{array}$ & $\begin{array}{c}\text { Reserves of mobile } \\
\text { P, } \mathrm{kg} \mathrm{ha}^{-1}\end{array}$ & $\begin{array}{c}\% \text { of mobile } \mathrm{P} \text { in its } \\
\text { total content }\end{array}$ \\
\hline \multicolumn{7}{|c|}{ Haplic Kastanozem,virgin } \\
\hline $\mathrm{A}_{1}$ & $0.5-18$ & $0.120 \mathrm{a}$ & $2.84 \mathrm{a}$ & $14.2 \mathrm{a}$ & $335.5 \mathrm{a}$ & $11.8 \mathrm{a}$ \\
\hline $\mathrm{B}_{1}$ & $18-40$ & $0.112 \mathrm{a}$ & $3.51 \mathrm{~b}$ & $6.3 \mathrm{~b}$ & $107.0 \mathrm{~b}$ & $3.0 \mathrm{~b}$ \\
\hline \multirow[t]{3}{*}{$\mathrm{B}_{2}$} & $40-61$ & $0.129 \mathrm{ba}$ & $4.29 \mathrm{c}$ & $3.4 \mathrm{c}$ & $113.5 \mathrm{~b}$ & $2.6 \mathrm{~b}$ \\
\hline & $0-20$ & & 6.02 & & 347.7 & 7.2 \\
\hline & $0-50$ & & 8.45 & & 499.2 & 5.9 \\
\hline \multicolumn{7}{|c|}{ Haplic Kastanozem,19 years in fallow } \\
\hline $\mathrm{A}_{1}$ & $0-23$ & $0.135 \mathrm{c}$ & $4.55 \mathrm{c}$ & $16.3 \mathrm{~d}$ & $551.1 \mathrm{c}$ & $12.1 \mathrm{a}$ \\
\hline $\mathrm{B}_{1}$ & $23-37$ & $0.160 \mathrm{~d}$ & $3.49 \mathrm{~b}$ & $9.0 \mathrm{e}$ & 196.6d & $5.6 \mathrm{c}$ \\
\hline \multirow[t]{3}{*}{$\mathrm{B}_{2}$} & $37-57$ & $0.140 \mathrm{c}$ & $4.42 \mathrm{c}$ & $4.1 \mathrm{c}$ & $129.6 \mathrm{~b}$ & $2.9 \mathrm{~b}$ \\
\hline & $0-20$ & & 4.99 & & 479.2 & 7.6 \\
\hline & $0-50$ & & 10.92 & & 831.9 & 7.6 \\
\hline
\end{tabular}

Different letters is designed for a statistically significant difference within a column, at $p<0.05$

Tiessen et al (1984) reported that $\mathrm{P}$, despite its low solubility and strong affinity for soil mineral components, moves within soil horizons and may be leached even in semi-arid environments. Another reason for the greater concentrations of $\mathrm{P}$ in fallow soil might be past tillage and fertilization practices. The fallow soil was plowed to a depth of $22-25 \mathrm{~cm}$, and the soil was thoroughly soaked to that depth. Calcium carbonates occur at a depth of $30-35 \mathrm{~cm}$, while the effervescence line from $10 \% \mathrm{HCl}$ is located at a depth of $25-30 \mathrm{~cm}$. Therefore, the binding of some mobile forms of phosphorus was observed, while others were used by plants. Past long-term fertilizer application usually enhances $\mathrm{P}$ availability to crops and compensates for the immobilization that occurs at the beginning. This means that highly available $\mathrm{P}$ applied as a fertilizer promotes the flow of available to less available forms; in these soils, it would precipitate as Ca phosphates. This assumption is confirmed by the share of mobile $\mathrm{P}$ in the total amount in fallow and virgin soils in the surface horizon, which was not significantly different, indicating the binding of mobile $\mathrm{P}$ by calcium carbonate. 
In our study, tillage also could facilitate the incorporation of the most resistant forms into the most dynamic cycle of soil P (Suñer and Galantini 2016). In addition, greater root growth may contribute to a P increase in the arable layer (Motta et al. 2002). Nunes et al (2020) found that less disturbed soil contributed to accumulation of more labile forms of phosphorus compared to conventional soil tillage.

The potassium content of the soils studied varies across a wide range (0.5-3.0\%) (Table 6). The continuous biological uptake of potassium by herbaceous vegetation and its annual input from litter into the soil under natural conditions leads to the accumulation of total potassium. After entering the soil, biogenic potassium is not leached because of its affinity for the clay minerals; instead, it is fixed in place (Shevchenko and Kuznetsov 2012). The concentrations of $\mathrm{K}_{2} \mathrm{O}$ in both soils were similar in all soil horizons (Table 6). The highest K content was in the A1 horizons of both soils, which significantly decreased with the depth, from 27.7 and 27.4 to 10.3 and $10.8 \mathrm{mg} 100^{-1} \mathrm{~g}$ soil, respectively. Due to biogenic absorption, the bulk of nutritive $\mathrm{K}$ was accumulated in the upper soil layer. Also, because of the high content of clay, the mineral fixation of $\mathrm{K}$ occurred in the upper horizons. Considering that the studied soils are heavy clayey, and due to biogenic absorption, most $\mathrm{K}$ accumulated in the upper humus horizon of the soil. However, $\mathrm{K}$ reserves in fallow soil were $8.8 \%$ and $33.7 \%$ and $3.7 \%$ greater at soil depths of $0-20,0-50$ and $0-100 \mathrm{~cm}$, respectively, compared to its virgin analogue, indicating that a process of potassium accumulation process took place in the last 19 years of fallowing.

Table 6. Content of mobile potassium

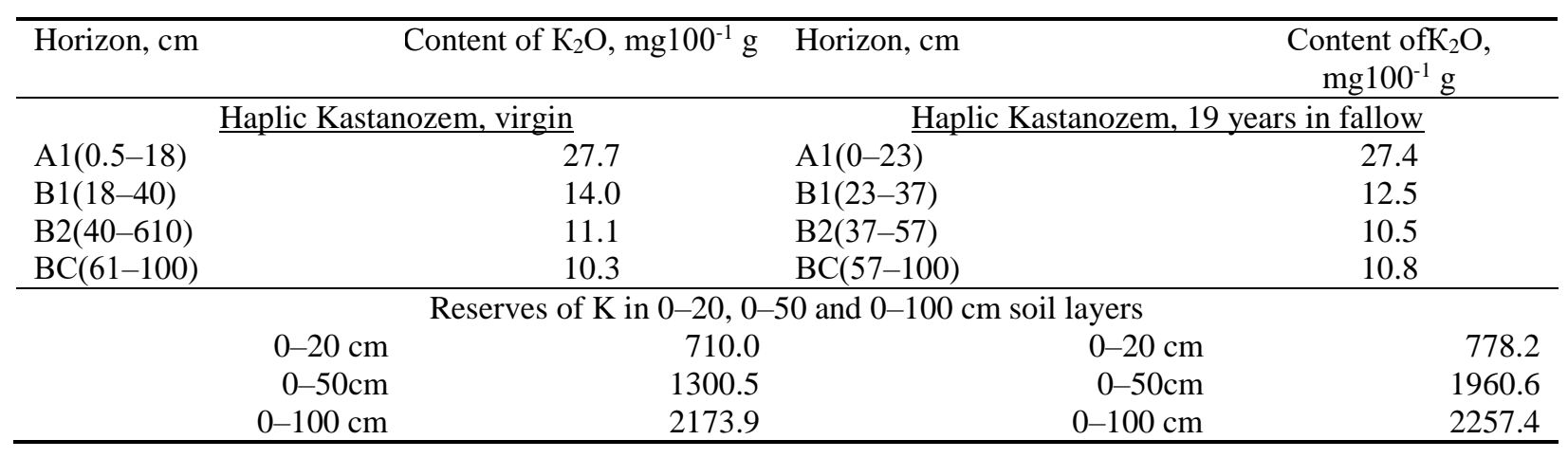

There are several possible reasons behind the greater reserves of $\mathrm{K}$ in fallow soils. One might be the fertilization history. Another could be that there is a greater clay fraction in the upper layer of the fallow soil which fixed $\mathrm{K}^{+}$, thus contributing to the increased potassium content in fallow soil. A number of studies have noted that an increase in the gross content of potassium accompanies a decrease in the size of the soil particles (Cui et al 2018). Additionally, the biogenic accumulation of $\mathrm{K}$ in fallow soils might contribute to the greater accumulation of mobile $\mathrm{K}$ in this soil, as potassium plays an important role in plant physiology and promotes water uptake through osmotic adjustment (Wang et al. 2013). Ions of $\mathrm{K}$ and Na have 
synergistic impacts on drought resistance in xerophytic dry-steppe plants (Cui et al. 2018), where xerophytes have the ability to efficiently use $\mathrm{K}^{+}$in a drought, even in soil conditions of $\mathrm{K}^{+}$deficiency (Cui et al. 2018).

\section{Exchangeable cations and salt regime}

The Haplic Kastanozems studied were characterized by a weakly alkaline soil reaction. Calcium predominated in the composition of exchangeable cations, followed by magnesium and sodium (Table 7).

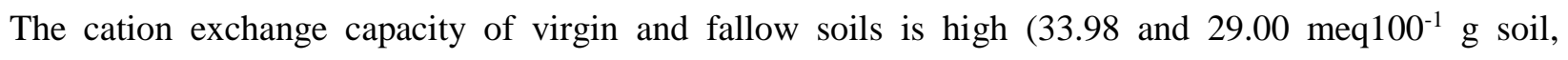
respectively). Weak soil alkalinity was observed in both soils. The soil CEC in fallow land was less for 4.08 meq $100^{-1} \mathrm{~g}$ compared to its virgin analogue.

Table 7. Amount of exchangeable cations

\begin{tabular}{|c|c|c|c|c|c|c|c|}
\hline \multirow{2}{*}{ Horizons, cm } & \multicolumn{3}{|c|}{$\begin{array}{c}\text { Exchangeable cations, } \% \text { of the } \\
\text { sum }\end{array}$} & \multicolumn{3}{|c|}{$\begin{array}{l}\text { Exchangeable cations, meq } 100^{-1} \mathrm{~g} \\
\text { soil }\end{array}$} & \multirow{2}{*}{$\begin{array}{l}\text { Sum of absorbed } \\
\text { bases, meq } 100^{-1} \mathrm{~g} \text { soil }\end{array}$} \\
\hline & $\mathrm{Ca}^{2+}$ & $\mathrm{Mg}^{2+}$ & $\mathrm{Na}^{+}$ & $\mathrm{Ca}^{2+}$ & $\mathrm{Mg}^{2+}$ & $\mathrm{Na}^{+}$ & \\
\hline \multicolumn{8}{|c|}{ Haplic Kastanozem, virgin } \\
\hline $\mathrm{A} 1(0.5-18)$ & 85.39 & 13.92 & 0.69 & 29.01 & 4.73 & 0.24 & 33.98 \\
\hline B1(18-40) & 79.63 & 17.25 & 3.12 & 14.03 & 3.03 & 0.36 & 17.62 \\
\hline $\mathrm{B} 2(40-610)$ & 78.77 & 18.00 & 3.23 & 11.23 & 2.56 & 0.44 & 14.26 \\
\hline $\mathrm{BC}(61-100)$ & 67.05 & 27.36 & 5.59 & 8.36 & 3.41 & 0.71 & 12.48 \\
\hline \multicolumn{8}{|c|}{ Haplic Kastanozem, 19 years in fallow } \\
\hline $\mathrm{A} 1(0.5-18)$ & 86.40 & 12.65 & 0.95 & 25.83 & 3.78 & 0.29 & 29.90 \\
\hline $\mathrm{B} 1(18-40)$ & 78.03 & 18.58 & 3.39 & 11.43 & 2.72 & 0.51 & 14.66 \\
\hline $\mathrm{B} 2(40-610)$ & 69.11 & 25.71 & 5.18 & 8.65 & 3.21 & 0.66 & 12.52 \\
\hline $\mathrm{BC}(61-100)$ & 65.10 & 28.53 & 6.37 & 6.82 & 3.06 & 0.60 & 10.48 \\
\hline
\end{tabular}

The most important cations determining the soil-absorbing complex of soil are $\mathrm{Ca}^{++}, \mathrm{Mg}^{++}, \mathrm{H}^{+}, \mathrm{Al}^{+++}$ and $\mathrm{Na}^{+}$. In alkaline soils, the cations of $\mathrm{Al}^{+++}$and $\mathrm{H}^{+}$are absent. The presence of $\mathrm{Na}^{+}$is associated with the extraction of $\mathrm{Na}^{+}$with soluble chloride salts and sulphates of sodium. The predominance of $\mathrm{Ca}^{++}$has two main reasons. The first is that these soils and rocks contain large amounts of calcium in primary calcareous minerals. The second is that, among other cations, $\mathrm{Ca}^{++}$is easily absorbed by clay minerals, especially humic substances (Martínez et al. 2007). The high content of $\mathrm{Ca}^{++}$in the lower horizons of both soils was mostly due to the calcareous rock material, while the sharp decrease in $\mathrm{Ca}^{++}$in the $\mathrm{B} 1$ and lower horizons can be explained by the drop in the humus content.

The content of $\mathrm{Mg}$ was distributed differently to $\mathrm{Ca}$ in both soils. Since these soils are characterized by approximately the same values with respect to the content and distribution of salts, this very large difference in the accumulation of $\mathrm{Mg}^{++}$can be explained by the composition of carbonates. Another reason might be the nature of $\mathrm{Mg}$ behavior in soil, which differs from that of $\mathrm{Ca}$. Although $\mathrm{Mg}$ is more mobile in 
soil due to its smaller radius than of $\mathrm{Ca}, \mathrm{K}$ and $\mathrm{Na}$, its hydrated radius is substantially larger (Maguire and Cowan 2002). Gransee and Führs (2013) showed that it is difficult to displace Mg from the lattice of minerals due to geochemical barriers, while the large ionic radius of $\mathrm{Ca}$ does not allow it to participate in the construction of the crystal lattice of minerals or be firmly fixed in soils (Sekine et al. 2017). This is especially true in the conditions of the dry steppe area.

Water extraction analysis indicated that there was moderate chloride salinization in both soils (Table 8). In contrast to the virgin soil, moderate salinity was revealed in the surface horizon of fallow soil. The soil alkalinity increases in the B1 horizon of both soils due to increased concentrations of all the studied anions and cations and the presence of sodium.

Table 8. Quantitative and qualitative composition of salts in the studied soils

\begin{tabular}{|c|c|c|c|c|c|c|c|c|c|c|}
\hline \multirow[t]{2}{*}{ Horizon, cm } & \multicolumn{4}{|c|}{$\begin{array}{c}\text { Anions, } \%, \\
\text { meq } 100^{-1} \mathrm{~g} \text { of soil }\end{array}$} & \multicolumn{3}{|c|}{$\begin{array}{c}\text { Cations, } \%, \\
\text { meq } 100^{-1} \mathrm{~g} \text { of soil }\end{array}$} & \multirow{2}{*}{$\begin{array}{l}\text { Type of } \\
\text { salinity }\end{array}$} & \multirow{2}{*}{$\begin{array}{c}\text { Degree of } \\
\text { salinity }\end{array}$} & \multirow{2}{*}{$\begin{array}{l}\text { Sum of } \\
\text { salts, \% }\end{array}$} \\
\hline & $\mathrm{CO}_{3}{ }^{-2}$ & $\mathrm{HCO}_{3}^{-}$ & $\mathrm{Cl}^{-}$ & $\mathrm{SO}_{4}^{-2}$ & $\mathrm{Ca}^{+2}$ & $\mathrm{Mg}^{+2}$ & $\mathrm{Na}^{+}$ & & & \\
\hline \multicolumn{11}{|c|}{ Haplic Kastanozem, virgin } \\
\hline $\mathrm{A}_{1}(0.5-18)$ & na & $\frac{0.0073}{0.12 \pm}$ & $\frac{0.0227}{0.64}$ & $\frac{0.0086}{0.18}$ & $\frac{0.0046}{0.23}$ & $\frac{0.0022}{0.19}$ & $\frac{0.0119}{0.52}$ & $\begin{array}{c}\text { Chlorid } \\
\mathrm{e}\end{array}$ & Weak & 0.0573 \\
\hline $\mathrm{B}_{1}(18-40)$ & - & $\frac{0.0109}{0.18}$ & $\frac{0.0493}{1.39}$ & $\frac{0.0182}{0.38}$ & $\frac{0.0104}{0.52}$ & $\frac{0.0083}{0.69}$ & $\frac{0.0182}{0.79}$ & $\begin{array}{c}\text { Chlorid } \\
\text { e }\end{array}$ & Moderate & 0.1153 \\
\hline $\mathrm{B}_{2}(40-610)$ & - & $\frac{0.0232}{0.38}$ & $\frac{0.0529}{1.49}$ & $\frac{0.0197}{0.40}$ & $\frac{0.0138}{0.69}$ & $\frac{0.0072}{0.60}$ & $\frac{0.0225}{0.98}$ & $\begin{array}{c}\text { Chlorid } \\
\text { e }\end{array}$ & Moderate & 0.1393 \\
\hline $\mathrm{BC}(61-100)$ & - & $\frac{0.0280}{0.46}$ & $\frac{0.572}{1.61}$ & $\frac{0.0326}{0.68}$ & $\frac{0.0148}{0.74}$ & $\frac{0.0075}{0.63}$ & $\frac{0.0317}{1.38}$ & $\begin{array}{c}\text { Chlorid } \\
\mathrm{e}\end{array}$ & Moderate & 0.1718 \\
\hline \multicolumn{11}{|c|}{ Haplic Kastanozem,19 years in fallow } \\
\hline $\mathrm{A}_{1}(0.5-18)$ & na & $\frac{0.005}{\frac{4}{7}}$ & $\frac{0.0291}{0.82}$ & $\frac{0.0096}{0.20}$ & $\frac{0.0076}{0.38}$ & $\frac{0.0018}{0.15}$ & $\frac{0.0133}{0.58}$ & $\begin{array}{c}\text { Chlorid } \\
\text { e }\end{array}$ & Moderate & 0.0668 \\
\hline $\mathrm{B}_{1}(18-40)$ & - & $\frac{0.015}{\underline{8}}$ & $\frac{0.0394}{1.11}$ & $\frac{0.0202}{0.42}$ & $\frac{0.0146}{0.73}$ & $\frac{0.0060}{0.50}$ & $\frac{0.0129}{0.56}$ & $\begin{array}{c}\text { Chlorid } \\
\mathrm{e}\end{array}$ & Moderate & 0.1089 \\
\hline $\mathrm{B}_{2}(40-610)$ & - & $\frac{0.018}{\frac{3}{3}}$ & $\frac{0.0575}{1.62}$ & $\frac{0.0177}{0.37}$ & $\frac{0.0152}{0.76}$ & $\frac{0.0062}{0.52}$ & $\frac{0.0232}{1.01}$ & $\begin{array}{c}\text { Chlorid } \\
\mathrm{e}\end{array}$ & Moderate & 0.1381 \\
\hline $\mathrm{BC}(61-100)$ & - & $\frac{0.023}{\underline{8}}$ & $\frac{0.0624}{1.76}$ & $\frac{0.0259}{0.54}$ & $\frac{0.0240}{1.20}$ & $\frac{0.0042}{0.35}$ & $\frac{0.0262}{1.14}$ & $\begin{array}{c}\text { Chlorid } \\
\mathrm{e}\end{array}$ & Moderate & 0.1665 \\
\hline
\end{tabular}

\pm Numerator - \%; denominator - milliequivalent per $100 \mathrm{~g}$ of soil

The formation of the cation exchange capacity in Kastanozems occurs with the incorporation of the exchangeable $\mathrm{Na}^{+}$into the soil CEC. The presence of soluble salts in the deeper horizons and parent rocks had a definite impact on the soil formation processes in the dry steppes, determining their alkalinity (Demkin et al. 2010). The presence of $\mathrm{Na}^{+}$in saline soils usually restricts plant growth. The appearance of alkalinity in the upper soil layers was associated with the biological absorption of sodium salts by some dry steppe plants, which have a deep root system. The xerophytes have developed a mechanism for effectively 
including the absorbed $\mathrm{Na}^{+}$in osmotic adjustment, thus simultaneously accumulating substantial $\mathrm{Na}^{+}$and $\mathrm{K}^{+}$in their leaves (Cui et al. 2018) and contributing to optimum plant growth under drought conditions.

The xerophytic dwarf shrubs absorbed solutions from deep horizons enriched with easily soluble salts, determining its ash composition with relatively high amounts of sodium. During the decomposition of plant residues, the soil solutions were relatively enriched in sodium, part of which was absorbed by organic and mineral colloidal soil substances.

\section{Vegetation cover of the studied soils}

The flora of the virgin site was represented by 54 species belonging to 44 genera and 14 families. The most dominant species were Asteraceae (11 species), Poaceae (8 species) and Fabaceae (5 species) (Table 9). Xeromesophytes (17 species) and xerophytes (15 species) dominated on virgin soil, followed by mesoxerophytes (14 species). There was a relatively diverse range of ephemeroids (Poaannua L., Allium rotundum L., Gagea bulbifera (Pall.), Tulipa biebersteiniana Schult. fil., Ornithogalum fischerianum Krasch., Iris pumila L.). Xerophilous shrubs dominated in the herbage: Artemisia austriaca Jacq.,A. lerchiana Weber, Tanacetum achilleifolium (M.Bieb.) Sch.Bip.

Table 9. Floristic list of species of vascular plants on experimental plots; the presence of a species on a plot is marked with a cross

\begin{tabular}{|c|c|c|c|}
\hline No. & Latin name & $\begin{array}{l}\text { Haplic Kastanozem, fallow for } \\
19 \text { years }\end{array}$ & Haplic Kastanozem,virgin \\
\hline & Poaceae Family & & \\
\hline 1 & Setaria viridis (L.) P.Beauv. & + & \\
\hline 2 & Stipa lessingiana Trin. et Rupr. & + & + \\
\hline 3 & Stipa capillata $\mathrm{L}$. & + & + \\
\hline 4 & Роа аппиа L. & + & + \\
\hline 5 & Koeleria gracilis Pers. & & + \\
\hline 6 & Festuca valesiaca Gaud. & + & + \\
\hline 7 & Bromus squarrosus L. & + & \\
\hline 8 & $\begin{array}{l}\text { Agropyron pectinatum (M.Bieb.) } \\
\text { P.Beauv. }\end{array}$ & + & + \\
\hline 9 & Elytrigia repens (L.) Desv. & & + \\
\hline 10 & $\begin{array}{l}\text { Leymus ramosus (Trin.) Tzvelev } \\
\text { Liliaceae Family }\end{array}$ & + & + \\
\hline 11 & Allium rotundum $\mathrm{L}$. & & + \\
\hline 12 & Gagea bulbifera (Pall.)Salisb. & & + \\
\hline 13 & Tulipa biebersteiniana Schult. fil. & & + \\
\hline 14 & $\begin{array}{l}\text { Ornithogalum fischerianum Krasch. } \\
\text { Iridaceae Family }\end{array}$ & & + \\
\hline 15 & $\begin{array}{l}\text { Iris pumila } \mathrm{L} \text {. } \\
\text { Polygonaceae Family }\end{array}$ & & + \\
\hline 16 & Rumex crispus $\mathrm{L}$. & & \\
\hline 17 & $\begin{array}{l}\text { Polygonum convolvulus } L \text {. } \\
\text { Chenopodiaceae Family }\end{array}$ & & \\
\hline 18 & Chenopodium album $\mathrm{L}$. & + & \\
\hline
\end{tabular}




\begin{tabular}{|c|c|c|c|}
\hline No. & Latin name & $\begin{array}{l}\text { Haplic Kastanozem, fallow for } \\
19 \text { years }\end{array}$ & Haplic Kastanozem,virgin \\
\hline 19 & Chenopodium rubrum L. & & + \\
\hline 20 & Chenopodium urbicum L. & + & \\
\hline 21 & Atriplex tatarica $\mathrm{L}$ & + & \\
\hline 22 & Atriplex patula $\mathrm{L}$ & + & \\
\hline 23 & Bassia hyssopifolia(Pall.) Kuntze & + & + \\
\hline 24 & $\begin{array}{l}\text { Salsola australis R.Br. } \\
\text { Amaranthaceae Family }\end{array}$ & + & \\
\hline 25 & $\begin{array}{l}\text { Amaranthus retroflexus } \mathrm{L} . \\
\text { Caryophyllaceae }\end{array}$ & + & \\
\hline 26 & Gypsophilia paniculata $\mathrm{L}$. & + & + \\
\hline 27 & Spergula sativa Boenn. & + & \\
\hline 28 & Silene nutans L. & & + \\
\hline 29 & $\begin{array}{l}\text { Scleranthus annuus L. } \\
\text { Brassicaceae Family }\end{array}$ & + & + \\
\hline 30 & Sisymbrium loeselii L. & + & \\
\hline 31 & Isatis tinctoria $\mathrm{L}$ & + & + \\
\hline 32 & $\begin{array}{l}\text { Descurainia Sophia (L.) Webb ex } \\
\text { Prantl }\end{array}$ & + & \\
\hline 33 & Camelina microcarpa Andrz. & + & \\
\hline 34 & Erysimum cheiranthoides L. & & + \\
\hline 35 & $\begin{array}{l}\text { Berteroa incana (L.) DC } \\
\text { Rosaceae Family }\end{array}$ & + & \\
\hline 36 & Spirea crenata L. & & + \\
\hline 37 & $\begin{array}{l}\text { Potentilla argentea L. } \\
\text { Fabaceae Family }\end{array}$ & & + \\
\hline 38 & & +Medicago sativa $\mathrm{L}$. & + \\
\hline 39 & Melilotus officinalis (L.) Desr. & + & \\
\hline 40 & Astragalus onobrychis L. & + & + \\
\hline 41 & Astragalus physodes L. & & + \\
\hline 42 & Astragalus testiculatus Pall. & & + \\
\hline 43 & $\begin{array}{l}\text { Glycyrhiza glabra L. } \\
\text { Euphorbiaceae Family }\end{array}$ & + & + \\
\hline 44 & $\begin{array}{l}\text { Euphorbia pseudagraria P.A.Smirn } \\
\text { Elaeagnaceae Family }\end{array}$ & + & \\
\hline 45 & $\begin{array}{l}\text { Eleagnus angustifolia L. } \\
\text { Apiaceae or Umbelliferae Family }\end{array}$ & & + \\
\hline 55 & Eryngium planum L. & + & \\
\hline 56 & Chaerophyllum prescottii DC & + & + \\
\hline 48 & Falcaria vulgaris Bernh. & + & \\
\hline 49 & Muretia lutea (M.Bieb.) Boiss. & & + \\
\hline 50 & $\begin{array}{l}\text { Ferula tatarica Fisch. ex Spreng. } \\
\text { Limonaceae Family }\end{array}$ & + & + \\
\hline 51 & $\begin{array}{l}\text { Goniolimon tataricum (L.)Boiss } \\
\text { Convolvulaceae Family }\end{array}$ & + & + \\
\hline 52 & $\begin{array}{l}\text { Convolvulus arvensis L. } \\
\text { Boraginaceae Family }\end{array}$ & + & + \\
\hline 53 & Nonea pulla (L.) DC. & & + \\
\hline 54 & $\begin{array}{l}\text { Onosma polychromum Klok. } \\
\text { Scrophulariaceae Family }\end{array}$ & + & + \\
\hline 55 & Linaria vulgaris Mill. & + & + \\
\hline 56 & Verbascum phoeniceum L. & + & \\
\hline 57 & Bobartia orientalis L. & + & \\
\hline 58 & Veronica spuria L. & & + \\
\hline
\end{tabular}




\begin{tabular}{|c|c|c|c|}
\hline No. & Latin name & $\begin{array}{c}\text { Haplic Kastanozem, fallow for } \\
19 \text { years }\end{array}$ & Haplic Kastanozem,virgin \\
\hline & Lamiaceae Family & & \\
\hline 59 & Salvia stepposa Shost. & + & + \\
\hline 60 & Dracocephalum thymiflorum L. & & + \\
\hline 61 & Phlomis pungens Wild. & & + \\
\hline 62 & $\begin{array}{l}\text { Phlomoides tuberosa (L.)Moench. } \\
\text { Rubiaceae Family }\end{array}$ & & + \\
\hline 63 & $\begin{array}{l}\text { Gallium ruthenicum Wild. } \\
\text { Dipsacaceae Family }\end{array}$ & + & + \\
\hline 64 & $\begin{array}{l}\text { Scabiosa ochroleuca L. } \\
\text { Asteraceae Family }\end{array}$ & & + \\
\hline 65 & Galatella villosa (L.) Rchb. f. & + & + \\
\hline 66 & Galatella linosyris (L.) Rchb. f. & + & + \\
\hline 67 & Helichrysum arenarium (L.) Moench & & + \\
\hline 68 & Erigeron canadensis $\mathrm{L}$. & + & \\
\hline 69 & Inula britannica $\mathrm{L}$. & & \\
\hline 70 & Inula salicina $\mathrm{L}$. & & + \\
\hline 71 & Achillea millefolium $\mathrm{L}$. & + & + \\
\hline 72 & $\begin{array}{l}\text { Tanacetum achilleifolium (M.Bieb.) } \\
\text { Sch.Bip. }\end{array}$ & + & \\
\hline 73 & Artemisia lerchiana Weber. & + & + \\
\hline 74 & Artemisia austriaca Jacq. & + & + \\
\hline 75 & Artemisia absinthium L. & + & \\
\hline 76 & Taraxacum officinale Wigg. & + & + \\
\hline 77 & Senecio jacobaea L. & + & \\
\hline 78 & Carduus acanthoides L. & + & \\
\hline 79 & Carduus crispus $\mathrm{L}$. & + & + \\
\hline 80 & Cirsium arvense (L.) Scop. & + & \\
\hline 81 & Centaurea scabiosa $\mathrm{L}$. & + & \\
\hline 82 & Tragopogon dubius Scop. & + & + \\
\hline 83 & Sonchus arvensis $\mathrm{L}$. & + & \\
\hline 84 & Lactuca serriola (L.) Tzvelev & + & + \\
\hline 85 & Lactuca tatarica (L.) C.A.Mey & + & \\
\hline & Total & 60 & 54 \\
\hline
\end{tabular}

The vegetation cover of the fallow site differed from the virgin steppe, and was negatively affected by its wheat cultivation history. The evolution of the flora after 19 years of fallow was at the stage of Leymus. 60 species of weed and native steppe plants belonging to 53 genera and 16 families were found.The predominance of plants in the Asteraceae (30\%) and Brassicaceae (8.3\%) families indicates that this former arable land has been infested with weeds since the time it was cultivated. The presence of weeds such as Setaria viridis, Chenopodium album, Amaranthus retroflexus, Polygonum convolvulus, Convolvulus arvensis, Sonchus arvensis L, Cirsium arvenseScop, Convolvulus arvensis L., Artemisia absinthium L., etc. also indirectly indicates the presence of a seed stock of these plants in the soil. This composition of growing wild vegetation does not represent any significant feeding value, and many of them are hard weeds. Although some are valuable drought-resistant, turf-forming perennial grasses (wheat grass, cereals, and fescue), it is not possible to spontaneously transform fallow land into environmentally sustainable, valuable 
hayfields and pastures in the next 10 years. This is evidenced by the powerful development of weed vegetation with a height of 30-50 cm and high density. Therefore, the seeds of wheat grass and fescue have no chance to form efficient plants in thickets of these weeds, as they die under the influence of highly developed weed vegetation.

Weeds are also known to be characterized by environmental plasticity and a variety of adaptations to seed transport, enabling them to be distributed in great numbers. A large seed bank remains in the soil that is able to maintain its germination for a long time (Laskurain et al. 2004); this factor should be taken into account when the fields are put to further agricultural use. According to the Raunkiær system (1937), the flora after 19years of fallow is dominated by hemicryptophytes (33 species, 55\%) and terophytes (16 species, 26.7\%), followed by therophytes and hemicryptophytes (biennials) (9 species, 15\%). Phanerophites and nanophanophites were represented by 2 species (3.3\%).

The fallow soil was characterized by a diverse range of life forms and a prevalence of perennial and annual grasses, where plants with a coreroot system were widespread (10/17\%), as were rhizomatous and long-rhizomal plants $(9 / 15 \%)$, and those with proliferous roots $(1 / 1.7 \%)$. This is a result of adaptation to sharp temperature fluctuations and lack of moisture. Meanwhile, the presence of annual and biennial plants $(18 / 30)$ was determined by the maximum precipitation in the spring and summer, as well as anthropogenic effects. The weeds with deep root systems are also responsible for the transposition of salts in the soil profile with the plant biomass, as was discussed in the previous section. The presence of 18 species of xerophytes and 15 species of mesoxerophytes indicates that the region has a sharply continental climate, distinguished by low air and soil humidity and large daily and seasonal temperature fluctuations. The presence of halophiles in the fallow site confirms the presence of soil areas with different levels of salinity.

The reduction in the anthropogenic impact (lack of grazing, plowing, mowing and the considerable distance from human settlements) helped the fields become covered by natural vegetation and encouraged the gradual restoration of steppe communities with cereal, white wormwood and mixed grass-feathergrasswhite wormwood combinations. After the transformation of arable soil in the fallow state, the composition and structure of the vegetation cover changes. The 19-year-old fallow, which is at a Leymus stage, is characterized by the following features: the dominance of weed-steppe species represented mainly by hemicryptophytes, where xeromesophytes, xerophytes and mesoxerophytes prevail.

\section{Conclusions}

1. Our preliminary study of Haplic Kastanozem showed that during 19 years of fallowing, the soil generally recovers its nutritional capacity in the plow layer, although the thickness of the humic horizon has been reduced and the depth of the salt layer has been elevated compared to its virgin analogue. 
2. Due to the high proportion of weeds in the 19 years fallow soil, the accelerated reformation of unused arable land (fallow land) into grasslands is of current importance. The further agricultural use of these fields should be planned taking into account both the composition and distribution of weeds and the salt dynamics in the soil profile.

3. To justify the further agricultural use of fallow ecosystems, it is necessary to monitor changes in the soil properties and vegetation cover of fallow lands as well as implementing some agronomical measures (fertilization) designed to improve their nutrient regime and adapt them for natural pastoral purposes.

Acknowledgment: Research was partially supported by the Ministry of Education, Science and Technological development of the Republic of Serbia (agreement no. 451-03-9/2021-14/200011)

\section{References}

Alewell C, Ringeval B, Ballabio C, Robinson DA, Panagos P, Borelli P (2020) Global phosphorus shortage will be aggravated by soil erosion. Nat Commun 11:4546 (2020). https://doi.org/10.1038/s41467-02018326-7

Cui YN, Xia ZR, Ma Q. et al. (2018) The synergistic effects of sodium and potassium on the xerophyticApocynumvenetum in response to drought stress. Plant PhysiolBiochemDOI: 10.1016/j.plaphy.2018.11.011

Demkin VA, Borisov AV, Demkina TS, Khomutova T, Kashirskaya NN (2010) Evolution of Soils and Dynamics of the Climate of Steppes in the Southeast of the Russian Plain During the Late Eneolithic and Bronze Ages (Fourth to Second Millennia BC). Eurasian Soil science 43(13):15151526DOI: $10.1134 / \mathrm{S} 1064229310130107$

Edelgeriev RSKh (2019) National report "Global climate and soil cover of Russia: desertification and land degradation, institutional, infrastructural, technological adaptation measures (agriculture and forestry). Volume 2, Moscow p. 476, https://cc.voeikovmgo.ru/images/sobytiya/2020/03/docclipoch.pdf

Espolov TI, Seyfullin ZT, Seitkazina GZh (2006) Economic and legal mechanism of land management. Almaty, pp. 33-34

Follett R, Kimble JM, Pruessner E, Samson-Leibig SE, Waltman Sh (2009) Soil organic carbon stocks with depth and land use at various U.S. sites. In: R. Lal and R. Follett, editors, Soil carbon sequestration and the greenhouse effect. 2nd ed. SSSA Spec. Publ. 57. SSSA, Madison, WI, p. 29-46

Funakawa S, Yanai J, Takata Y, Karbozova-Saljnikov E, Akshalov K, Kosaki K (2007) Dynamics of water and soil organic matter under grain farming in Northern Kazakhstan - Toward sustainable land use both from the agronomic and environmental viewpoints. In Climate Change and Terrestrial Carbon 
Sequestration in Central Asia.Eds. R. Lal, M. Suleimenov, B.A. Stewart, D.O. Hanson, and P. Doraiswamy.p.279-331, Taylor \& Francis, Leiden, Netherlands.

Gransee A, Führs H (2012) Magnesium mobility in soils as challenge for soil and plant analysis, magnesium fertilization and root uptake under adverse growth conditions. Plant and Soil 368 (1-2):5-21. https://doi.org/10.1007/s11104-012-1567-y

Gumarova Zh M, Bulekova AA (2017) Potential fertility and water regime of deposit dark chestnut soils in Western Kazakhstan. Zemljiste i Biljka 66(1):1-9

Helfenstein J, Pistocchi Ch, Oberson A, Tamburini F, Goll DS, Frossard E (2020) Estimates of mean residence times of phosphorus in commonly considered inorganic soil phosphorus pools. Biogeosciences, 17(2):441-454, https://doi.org/10.5194/bg-17-441-2020

Hobley E, Willgoose GR, Frisia, Jacobsen G (2013) Environmental and site factors controlling the vertical distribution and radiocarbon ages of organic carbon in a sandy soil. Biology and Fertility of Soils 49:1015-1026.

Hoffland E, Kuyper TW, Comans RNJ, Cereamer RE (2020) Eco-functionality of organic matter in soils. Plant Soil 455:1-22, https://doi.org/10.1007/s11104-020-04651-9

Kadono A, FunakawaSh, Kosaki T (2008) Factors controlling mineralization of soil organic matter in the Eurasian steppe. Soil boilBiochem, 40(4):947-955

Karavaev NA, Denisenko EA (2008) Postagrogenic restoration of the properties of chernozem and vegetation on dated deposits of Central Chernozem Region Proc of the All-Russian Scientific Conference Agroecological status and prospects for the use of land in Russia, alienated from active agricultural use, Dokuchaev Soil Institute, Moscow Russian Academy of Agricultural Sciences, pp 303306

Kazeev K Sh, Trushkov AV, Odabashyan My, Kolesnikov SI (2020) Postagrogenic changes in the enzyme activity and organic carbon content in Chernozem during the first three years of fallow regime. Eurasian Soil Sci DOI: 10.1134/s1064229320070054

Kechaikina IO, Ryumin AG, Chukov SN (2011) Postagrogenic transformation of organic matter in soddypodzolic soils. Eurasian Soil Sci. 44(10):1077-1089. https://doi.org/10.1134/S1064229311100061 [accessed Nov 09 2020].

Keller T, Sandin M, Colombi T, Horn R, Or D (2019) Historical increase in agricultural machinery weights enhanced soil stress levels and adversely affected soil functioning. Soil Tillage Res 194:104293.

Khudyakova VM (2015) Granulometric composition, physico-chemical and agrochemical properties of Dark Chestnut soils of different economic use in the conditions of Western Kazakhstan. Doctoral Thesis St. Petersburg - Pushkin 
Kodiwo M, Oindo B, Ang'awa F (2014) Intensity of Farmland Cultivated and Soil Bulk Density in Different Physiographic Units In Nyakach District. IOSR Journal Of Humanities And Social Science (IOSR-JHSS) 19(1):86-91

Koniak G, Noy-Meir I (2009) A hierarchical, multi-scale, management-responsive model of Mediterranean vegetation dynamics. Ecol Model 220:1148-1158.

Kovda V (1947) The Genesis and Regime of Salt Affected Soils, Vol 2, Izd Academy Moscow-Leningrad Publ, USSR

Lajtha K, Bloomer SH (1988) Factors affecting phosphate sorption and phosphate retention in a desert ecosystem. Soil Sci 146. 160-167

Laskurain NA, Escudero A, Olano JM, Loidi J (2004) Seedling dynamics of shrubs in a fully closed temperate forest: greater than expected. Ecography 27:650-658. [Google Scholar]

Li Zh, Zeng Zh, Tian D, Wang J, Fu Zh, Zhang F, Zhang R, Chen W, Luo Y, Niu Sh (2020) Glovbal patterns and controlling factors of soil nitrification rate. Global Change Biology 26(7):4147-4157 https://doi.org/10.1111/gcb.15119

Maguire ME, Cowan JA (2002) Magnesium Chemistry and Biochemistry. Biometals 15:203210 http://dx.doi.org/10.1023/A:1016058229972

Martínez RS, Zalba P, Villamil MB, Peinemann N (2007) Organic matter mobilization as affected by soilsolution composition and prevailing clay minerals. Commun Soil Sci Plant Analys 33(13-14):22912299 DOI: $10.1081 /$ CSS-120005763

Mineev VG (2001) Workshop on Agricultural Chemistry: Textbook, Moscow State University Publ. p 689 (Практикум по агрохимии: Учеб. Пособие)

Motta ACV, Reaves DW, Touchton JT (2002) Tillage intensity effects on chemical indicators of soil quality in two coastal plain soils.Commun. Soil Sci Plant Anal 33:913-932

Nunes RS, de Sousa DMG, Goedert WJ, de Oliveira LEZ, Pavinato PS and Pinheiro TD (2020) Distribution of Soil Phosphorus Fractions as a Function of Long-Term Soil Tillage and Phosphate Fertilization Management. Front. Earth Sci 8:350. doi: 10.3389/feart.2020.00350

Rakhimgaliyeva SZh, Khudyakova VM (2010) Content and reserves of phosphorus in Dark Chestnut soils of Western Kazakhstan with their different use. News of St. Petersburg State Agrarian University 18:6468

Rakhimgaliyeva SZh, Khudyakova VM (2011) Cation exchange capacity and composition of exchange cations in Dark Chestnut soils in Western Kazakhstan with different uses. News of St. Petersburg State Agrarian University 25:30-34 
Rakhimgaliyeva SZh, Sukhanberdina LKh, Volodin MA, Esbulatova AZh, Zainullin MB (2013) Humus state of fallow dark chestnut soils. Proceedings of the International Scientific Conference The current state of chernozem, Rostov-on-Don, Pp 245-247

Raunkiær Ch (1937) Plant life forms / transl. from Danish by H. Gilbert-Carter. Oxford, Clarendon Press, vi, $104 \mathrm{p}$

Ray von W (2006) Phosphorus retention in calcareous soils and the effect of organic matter on its mobility, Geochem Trans 7(6): doi: 10.1186/1467-4866-7-6, PMID: 16768791

Risch AC, Zimmermann S, Ochoa-Hueso R. et al. (2019) Soil net nitrogen mineralisation across global grasslands. Nat Commun 10:4981. https://doi.org/10.1038/s41467-019-12948-2

Saljnikov E, Cakmak D, Muhanbet A, Kresovic M (2017) Biological indices of soil organic matter in long $\begin{array}{lllll}\text { term fertilization } & \text { Zemljiste } & \text { i } & \text { Biljka } & \text { 63(2):11-20 }\end{array}$ http://www.sdpz.rs/images/casopis/2014/ZIB_vol63_no2_2014_pp11-20.pdf

Saljnikov E, Cakmak D, Rahimgalieva S (2013) Soil Organic Matter Stability as Affected by Land Management in Steppe Ecosystems, Chapter 10 In Soil Processes and Current Trends in Quality Assessment, INTECH, http://dx.doi.org/10.5772/53557, pp. 269-310

Schlesinger WH, PilmanisAM (1998) Plant-soil interactions in deserts. Biogeochemistry 42:169-187

Sekine Yu, Motokawa R, Kozai N, et al (2017) Calcium-deficient Hydroxyapatite as a Potential Sorbent for Strontium. Scientific Reports 7, no. 2064, https://www.nature.com/articles/s41598-017-02269-z

Shang ZH, Cao JJ, Degen AA, Zhang DW, Long RJ (2019) A four year study in a desert land area on the effect of irrigated, cultivated land and abandoned cropland on soil biological, chemical and physical properties. Catena 175:1-8. https://doi.org/10.1016/j.catena.2018.12.002 [accessed Nov 09 2020].

Shennikov AP (1964) Introduction into geobotanics. Leningrad, Leningrad State University Publishing, p. 447

Shevchenko EN, Kuznetsov AN (2012) Demutation of vegetation cover on the deposits of the Saratov Trans-Volga region. Bulletin of the Orenburg State University 6(38):8-10

Suleymanov R, Yaparov I, Saifullin I, Vildanov I, Shirokih PS, Suleymanov A, Komissarov M, Liebelt P, Nimatullin A, Khamidullin R (2020) The current state of abandoned lands in the northern forest- steppe zone at the Republic of Bashkortostan (Southern Ural, Russia). Spanish J Soil Sci 10(1):29-44 DOI: $\underline{10.3232 / S J S S .2020 . V 10 . N 1.03}$

Suñer L, Galantini JA (2016) Phosphorus dynamic in the soil-plant system under different management practices in semiarid pampas. https://www.researchgate.net/publication/317760251_Phosphorus_dynamic_in_the_soilplant_system_under_different_management_practices_in_semiarid_pampas 
Telesnina VM, Zhukov MA (2019) The influence of agriculture method on dynamic of biological cycling and some soil properties due to post-agrogenic succession (Kostroma region). Eurasian Soil Sci. 52(9):1122-1136. https://doi.org/10.1134/S1064229319070135 [accessed Nov 09 2020].

Tiessen H, Stewart JW, Cole CV (1984) Pathways of Phosphorus Transformations in Soils of Differing Pedogenesis Soil SciSoc Am J 48(4) DOI: 10.2136/sssaj1984.03615995004800040031x

Titlyanova AA, Kiryushin VI, Okhinko IP (1984) Agrocenoses of steppe zone, Novosibirsk, Nauka

Toner JD, Catling DC (2020) A carbonate-rich lake solution to the phosphate problem of the origin of life. PNAS 117(2):883-888, https://doi.org/10.1073/pnas.1916109117

Veenstra JJ, Burras CL (2015) Soil Profile Transformation after 50 Years of Agricultural Land Use. Soil SciSoc Am J 79:1154-1162 doi:10.2136/sssaj2015.01.0027

Wang M, Zhen Q, Shen Q, GuoSh (2013) The Critical Role of Potassium in Plant Stress Response. Intern J Molecular Sci 14(4):7370-90 DOI: 10.3390/ijms 14047370

Weeks Jr JJ, Hettiarachchi GM (2019) A Review of the latest in phosphorus fertilizer technology: Possibilities and pragmatism. J Environ Qual 48(5):1300-1313 https://doi.org/10.2134/jeq2019.02.0067 WRB (2015) World reference base for soil resources 2014. Food and Agriculture Organization of the United Nations Rome, 2015

Xie QY, Zhang MY, Gao YH (2016) Variation of mechanical composition, nutrition and microbial activity of alpine meadow soil in greenhouses with cultivation age on the Qinghai-Tibet Plateau. Journal of Ecology and Rural Environment 32(4):603-608.

Zhang W, Ren C, Deng J, Zhao F, Yang G, Han X, Tong X, Feng Y (2018) Plant functional composition and species diversity affect soil $\mathrm{C}, \mathrm{N}$, and $\mathrm{P}$ during secondary succession of abandoned farmland on the Loess Plateau. Ecol Eng. 122:91-99. https://doi.org/10.1016/j.ecoleng.2018.07.031 [accessed Nov 09 2020]. 


\title{
How withdrawing arable land affected the productive capacity of Haplic Kastanozems after 19 years of fallowing in dry steppes of the Ural piedmont
}

\author{
Saule Rakhimgaliyeva ${ }^{1}$, Sonja Tošic ${ }^{2}$, Frank Eulenstein $^{3}$, Uwe Schindler $^{4}$, Elmira Saljnikov $^{2 *}$
}

\author{
${ }^{1}$ West Kazakhstan Agrarian Technical University, Zhangir Khan 51, Uralsk, Kazakhstan \\ ${ }^{2}$ Soil Science Institute, TeodoraDrajzera 7,11000 Belgrade, Serbia \\ ${ }^{3}$ Leibniz-Centre for Agricultural Landscape Research (ZALF), 15374 Müncheberg, Eberswalder Str. 84, Germany, \\ ${ }^{4}$ Mitscherlich Academy for Soil Fertility (MITAK), GmbH, 14641 Paulinenaue, Prof.-Mitscherlich-Allee 1, \\ Germany,
}

${ }^{*}$ Corresponding author: Elmira Saljnikov, soils.saljnikov@gmail.com

\section{Izvod}

Plodne oranice u sušnoj stepskoj zoni uralskog pijemonta, koje su se intenzivno koristile za proizvodnju zitarica 30 godina prošlog veka, povučene su iz obrade i napuštene poslednjih 20 godina. Nova strategija Republike Kazahstan za obnavljanje produktivnosti prirodnih pašnjaka predstavlja izazov za naučnike kada je u pitanju obnavljanje prirodnih svojstava zemljišta u svojstvo prorodnih pašnjaka proučavanog zemljišta crnog kestena (Haplic Kastanozems). U ovoj studiji su predstavljeni rezultati projekta posvećenog istraživanju promena fizičke i hemijske morfologije zemljišta usled prethodne istorijske kultivacije Haplic Kastanozems, koje je poslednjih 19 godina u stanju ugara. Neke promene morfoloških karakteristika zemljišta su uzrokovane promenama fizičkih osobina zemljišta usled dugotrajnog perioda obrade zemljišta u prošlosti. Promene uočene u agrohemijskim karakteristikama zemljišta su posledica promena fizičkih osobina zemljišta i đjubrenja u prošlosti. Uočen je minimalan porast saliniteta zemljišta zbog veće akumulacije rastvorljivih soli $\mathrm{u}$ obradivom sloju ugara $\mathrm{u}$ poređenju sa njegovim netaknutim Haplic Kastanozems analogom. Promene i prelaze u sastavu vegetacije treba dalje istražiti, i razviti tehnike za ubrzanu obnovu zemljišta ugara u suvim stepama zapadnog Kazahstana.

Ključne reči: Haplic Kastanozem, ugar, devičansko zemljište, flora, morfologija, humus distribucija veličina čestica, rastvorljive soli 